Original Research Paper

\title{
Extraction, Partial Identification and Bioactivities of Total Flavonoids from Carex meyeriana Kunth
}

\author{
Hongbiao Wang, Penghui Wang, Xiudong Yang, Xianhe Cheng, Mengrou Dong, Yuejiao Guo, \\ Chun Liu, Ziqiang Yan and Hongli Zhou \\ School of Chemistry and Pharmaceutical Engineering, \\ Jilin Institute of Chemical Technology, Jilin 132022, PR China
}

\author{
Article history \\ Received: 07-06-2019 \\ Revised: 05-07-2019 \\ Accepted: 30-07-2019 \\ Corresponding Author: \\ Hongli Zhou \\ School of Chemistry and \\ Pharmaceutical Engineering, \\ Jilin Institute of Chemical \\ Technology, Jilin 132022, PR \\ China \\ Tel: +86-432-62185246 \\ E-mail: zhouhongli@jlict.edu.cn
}

\begin{abstract}
To date, knowledge associated with extraction, chemical constituents and bioactivities of Total Flavonoids from Carex meyeriana Kunth (TFCMK) that remains unclear. Therefore, this paper was designed to optimize the ethanol reflux extraction method by response surface methodology and determine the chemical constituents by Liquid Phase-Mass Spectrometry (HPLC-MS); additionally, the bioactivities including antioxidant, antibacterial and hemolysis test were also explored. The maximum TFCMK extraction yield of $6.248 \% \pm 0.016 \%$ was obtained under the optimal conditions as follows: Ethanol concentration $50 \%$, ratio of liquidto-solid $31 \mathrm{~mL} / \mathrm{g}$, extraction time $91 \mathrm{~min}$ and extraction temperature $71^{\circ} \mathrm{C}$. Meanwhile, 9 compounds of TFCMK were identified by using LP-MS for the first time. In addition, TFCMK showed higher antioxidant activity compared with vitamin $\mathrm{C}$, as evidenced by the lower $\mathrm{EC}_{50}$ or $\mathrm{IC}_{50}$ of TFCMK (reducing power assay: $0.125 \pm 0.025 \mathrm{mg} / \mathrm{mL}$, DPPH radicals: $0.28 \pm 0.031$, $\mathrm{ABTS}^{+}$radicals: $0.012 \pm 0.005$, hydroxyl radicals: $0.028 \pm 0.008 \mathrm{mg} / \mathrm{mL}$; The $\mathrm{EC}_{50}$ or $\mathrm{IC}_{50}$ of $\mathrm{VC} 0.156 \pm 0.012,0.059 \pm 0.019,0.068 \pm 0.024$ and $0.032 \pm 0.007$ $\mathrm{mg} / \mathrm{mL}$, respectively.). Broth microdilution assays had demonstrated that the minimal inhibitory concentrations (MICs) of TFCMK on Bacillus pumilus, Bacillus subtilis and Escherichia coli were $0.625 \pm 0.0032$, $1.250 \pm 0.0216$ and $5.000 \pm 0.0205 \mathrm{mg} / \mathrm{mL}$, respectively. Besides, the hemolysis rate (less than 5\%) in vitro implied that TFCMK possessed a good blood compatibility. In summary, this paper provides evidences that TFCMK might be applied as an antioxidant and antibacterial agent in the pharmaceutical and chemical industries.
\end{abstract}

Keywords: Carex meyeriana Kunth, Total Flavonoids, Extraction, Antioxidant, Antibacterial, Hemolysis Test, Response Surface Methodology, Liquid Phase-Mass Spectrometry

\section{Introduction}

Carex meyeriana Kunth (CMK), a perennial herb belonging to a genus Cares species in the family Cyperaceae, is widely distributed in China including Heilongjiang, Jilin, Inner Mongolia and Sichuan (Reznicek, 1990) and other countries such as Far East Russia, Mongolia, Korea and Japan (Yang et al., 2017a). The shoe pads, waist supports, mattress and other daily necessities made of CMK as the main material can keep warm and actively absorb moisture and they are hard to self-corrode (Luo and Zhang, 2008). CMK is a valuable germplasm resource and CMK together with the Panax ginseng C.A. Mey and pelt of marten is called "three treasures in Northeast China" (Yun et al., 2016). In our previous study, polysaccharides (Hu et al., 2018) and essential oils (Cui et al., 2018) of CMK were explored in the details. However, there has been no report on its flavonoids and their extraction process and chemical composition, especially bioactivities.

The traditional ethanol reflux extraction method (Yang et al., 2016) is nondestructive to the target product and featured by less impurities, mildew proofness and easy preservation. In order to improve the extraction yield of flavonoids, Response Surface Methodology (RSM) has been widely employed in 
various extraction processes to determine the best experimental parameters, evidenced by the true limit state surface and statistical significance of the independent variables (Wang et al., 2017). Time-ofFlight (TOF)-MS and Liquid Chromatography (LC) can be used to analyze the quality of complex compounds and to better separate flavonoids (Dong et al., 2017). The antioxidant activity of flavonoids is usually evaluated through the reduction ability of $\mathrm{Fe}^{2+}$, scavenge DPPH free radicals, $\mathrm{ABTS}^{+}$free radicals and hydroxyl free radicals.

The optimum extraction process of TFCMK by ethanol reflux was determined through RSM and the chemical constituents were studied by Liquid Chromatography-Mass Spectrometry (LC-MS); more importantly, the antioxidant, antibacterial activity and lysis erythrocytes in vitro were investigated. Taken together, this paper is the first time to systematically explore the basic research of TFCMK, thereby providing a scientific basis for the development and utilization of TFCMK.

\section{Materials and Methods}

\section{Materials}

Carex meyeriana Kunth (CMK) samples were collected from a wetland in the northern suburbs of Jiamusi, Northeast China $\left(45^{\circ} 56^{\prime} \mathrm{N}, 1^{2} 9^{\circ} 29^{\prime} \mathrm{E}\right)$. The ground part of CMK was identified by Prof. Guangshu Wang (Jilin University, China). The herbarium samples (Voucher No. TFCMK -04) were deposited at School of Chemistry and Pharmaceutical Engineering, Jilin Institute of Chemical Technology, Jilin, China. TFCMK were placed in a semi-dark room for natural drying. Diphenyl Picrylhydrazinyl (DPPH) and 2, 2'-azinobis (3ethylbenzothiazoline-6-sulfonic acid) (ABTS) (both Aladdin, St. Shanghai, China) and L-Ascorbic acid (VC, Hushi, St. Shanghai, China) were used. All reagents and solvents were the analytical grade. All the bacterial strains including Bacillus subtilis ATCC 6633, Bacillus pumilus ATCC 700814 and Escherichia coli ATCC 25922 were purchased from Beijing Zhongke Quality Inspection Biotechnology Co. Ltd. The hemolysis of TFCMK was assessed by evaluating the lysis of human Red Blood Cells (hRBCs) obtained from the General Hospital of Jilin Chemical Group Corporation (Jilin, Jilin, China).

\section{Methods}

\section{Extraction Experiment}

Five gram of the CMK crushed was placed in a 250 $\mathrm{mL}$ round-bottom flask together with the extracting solvent, followed by extraction at appropriate ethanol concentration, liquid-to-material ratio, extraction time and temperature. After that, the samples were filtered and dried on a freeze dryer.

\section{Determination of Total Flavonoid Content}

The content of total flavonoids was determined by sodium nitrite chromogenic method (Liu et al., 2012). The standard reserve solutions of rutin were accurately prepared at $510 \mathrm{~nm}$ on an ultraviolet spectrophotometer. Results showed the linear equation was $Y=$ $14.548 x+0.0013\left(R^{2}=0.9997\right)$ in the linear range of 0 $0.06 \mathrm{mg} / \mathrm{mL}$. The extraction rate of TFCMK was calculated as follows:

Extraction rate of TFCMK $=\left[\left(C \times V \times 10^{-3}\right) / M\right] \times 100 \%$

where, $C, V$ and $M$ are the concentration of TFCMK $(\mathrm{mg} / \mathrm{mL})$, dilution multiple $(\mathrm{mL})$ and quality of TFCMK (g), respectively.

\section{Optimization of Extraction Technology by BBD-RSM}

According to RSM and Box-Behnken central composite experiment Design (BBD), the four factors of ethanol concentration $\left(X_{1}, \%\right)$, liquid-to-material $\operatorname{ratio}\left(X_{2}, \mathrm{~mL} / \mathrm{g}\right)$, extraction time $\left(X_{3}, \min \right)$ and extraction temperature $\left(X_{4}\right.$, ${ }^{\circ} \mathrm{C}$ ) were optimized and defined as three horizontal levels of high (+1), medium (0) and low (-1) (Table 1). The factors were coded as follows (Mou et al., 2017):

$X_{i}=\left(x_{i}-x_{0}\right) / \Delta x_{i}$

where, $X i$ and $x_{i}$ are the coded and actual values of the independent variable, respectively, $x_{0}$ is the actual value of the independent variable at the central point and $\Delta x_{i}$ is the step of the variable.

With the extraction rate of TFCMK as the response value, the BBD experiment was designed on DesignExpert V 8.0.6.1 Trial. The four-factor and three-level response surface analysis was established involving 24 groups of factorial experiments and 5 groups of center experiments (Table 2).

The quadratic polynomial regression equation for optimization was fitted as follows (Chen et al., 2012):

$$
Y=\beta_{0}+\sum_{i=1}^{n} \beta_{i} X_{i}+\sum_{i=1}^{n} \beta_{i i} X_{i}^{2}+\sum_{i<j}^{n} \beta_{i j} X_{i} X_{j}+\varepsilon
$$

where, $Y$ is the predicted extraction rate of TFCMK and $\beta_{0}$ is the constant coefficient; the first-order coefficients of $\beta_{i}$, $\beta_{i i}$ and $\beta_{i j}$ are $X_{i}$; the second-order coefficients and the interaction influence are the experimental errors (random).

\section{Chemical Composition Analysis of TFCMK by HPLC-ESI-Q-TOF MS/MS}

The flavonoids were dissolved in a small amount of acetonitrile into a reserve solution at a certain concentration. 
Table 1: Independent variables and levels used for box-behnken design

\begin{tabular}{|c|c|c|c|c|c|}
\hline \multirow[b]{2}{*}{ Factors } & \multirow[b]{2}{*}{ Units } & \multirow[b]{2}{*}{ Code } & \multicolumn{3}{|c|}{ Levels and range } \\
\hline & & & -1 & 0 & +1 \\
\hline Ethanol concentration & $\mathrm{v} / \mathrm{v}$ & $\mathrm{X}_{1}$ & 40 & 50 & 60 \\
\hline Liquid-solid ratio & $\mathrm{mL} / \mathrm{g}$ & $\mathrm{X}_{2}$ & 20 & 30 & 40 \\
\hline Extraction time & $\min$ & $\mathrm{X}_{3}$ & 60 & 90 & 120 \\
\hline Extraction temperature & ${ }^{\circ} \mathrm{C}$ & $\mathrm{X}_{4}$ & 60 & 70 & 80 \\
\hline
\end{tabular}

Table 2: Design and results of responsse surface experiment

\begin{tabular}{|c|c|c|c|c|c|}
\hline No. & $\mathrm{X}_{1}$ & $\mathrm{X}_{2}$ & $\mathrm{X}_{3}$ & $\mathrm{X}_{4}$ & $Y \%$ \\
\hline$\overline{1}$ & -1 & -1 & 0 & 0 & 1.46 \\
\hline 2 & 1 & -1 & 0 & 0 & 1.84 \\
\hline 3 & -1 & 1 & 0 & 0 & 2.70 \\
\hline 4 & 1 & 1 & 0 & 0 & 1.30 \\
\hline 5 & 0 & 0 & -1 & -1 & 2.06 \\
\hline 6 & 0 & 0 & 1 & -1 & 1.90 \\
\hline 7 & 0 & 0 & -1 & 1 & 2.95 \\
\hline 8 & 0 & 0 & 1 & 1 & 2.63 \\
\hline 9 & -1 & 0 & 0 & -1 & 2.62 \\
\hline 10 & 1 & 0 & 0 & -1 & 2.12 \\
\hline 11 & -1 & 0 & 0 & 1 & 2.66 \\
\hline 12 & 1 & 0 & 0 & 1 & 2.12 \\
\hline 13 & 0 & -1 & -1 & 0 & 1.43 \\
\hline 14 & 0 & 1 & -1 & 0 & 2.19 \\
\hline 15 & 0 & -1 & 1 & 0 & 2.14 \\
\hline 16 & 0 & 1 & 1 & 0 & 2.77 \\
\hline 17 & -1 & 0 & -1 & 0 & 2.56 \\
\hline 18 & 1 & 0 & -1 & 0 & 2.01 \\
\hline 19 & -1 & 0 & 1 & 0 & 2.51 \\
\hline 20 & 1 & 0 & 1 & 0 & 2.39 \\
\hline 21 & 0 & -1 & 0 & -1 & 2.45 \\
\hline 22 & 0 & 1 & 0 & -1 & 2.46 \\
\hline 23 & 0 & -1 & 0 & 1 & 2.29 \\
\hline 24 & 0 & 1 & 0 & 1 & 2.44 \\
\hline $25^{*}$ & 0 & 0 & 0 & 0 & 6.08 \\
\hline $26^{*}$ & 0 & 0 & 0 & 0 & 6.03 \\
\hline $27 *$ & 0 & 0 & 0 & 0 & 6.12 \\
\hline $28^{*}$ & 0 & 0 & 0 & 0 & 6.58 \\
\hline $29 *$ & 0 & 0 & 0 & 0 & 6.36 \\
\hline
\end{tabular}

*Five replicates of central point

HPLC conditions were as follows: Symmetry ${ }^{\circledR}$ C18 $(5 \mu \mathrm{m}, 4.6 \times 250 \mathrm{~mm})$; injection volume of $5 \mu \mathrm{L}$; mobile phase containing $0.1 \%$ formic Acid (A) and acetonitrile (B). The elution gradient of the mobile phase was as follows: $0-25 \mathrm{~min}, 85-65 \% \mathrm{~A}$; $25-35 \mathrm{~min}, 60-45 \% \mathrm{~A}$; $35-$ $50 \mathrm{~min}, 45-20 \% \mathrm{~A}$; $50-55 \mathrm{~min}, 20-0 \% \mathrm{~A}$; 55-60 min, 0\%A; 60-60.1 min, 0-15\%A; 60.1-66 min, 15\%A.

The MS conditions in negative mode were as follows: injection voltage of the ESI source at $4000 \mathrm{~V}$, dry gas volume flow rate at $1 \mathrm{~L} / \mathrm{min}$, atomization gas pressure 30 psi, auxiliary gas pressure $60 \mathrm{psi}$, interface continuous heating and a TOF-MS detector (Agilent Technologies, Santa Clara, CA, USA). The MS ion source was operated at $300^{\circ} \mathrm{C}$ and a scan mass range of $\mathrm{m} / \mathrm{z} 100-1500$.

\section{Antioxidant Activity}

Four systems were used to evaluate antioxidant activity of TFCMK in vitro and VC was served as the positive control. The reducing power was determined following a reported protocol with TFCMK and VC solutions (0.004, 0.008, 0.016, 0.032, $0.068 \mathrm{mg} / \mathrm{mL})$ (Mendes et al., 2011). The results were expressed as the effective concentration at 0.5 absorbance unit $\left(\mathrm{EC}_{50}\right)$.

The DPPH scavenging rate was determined by using an existing protocol with TFCMK solutions (0.004, $0.008,0.016,0.032,0.068 \mathrm{mg} / \mathrm{mL}$ ) and $\mathrm{VC}$ solutions (0.001, 0.003, 0.005, 0.009, $0.012 \mathrm{mg} / \mathrm{mL}$ ) (Wang et al., 2016). The $\mathrm{IC}_{50}$ was expressed as the inhibition concentration at $50 \%$ clearance rate.

The $\mathrm{ABTS}^{+}$scavenging rate was determined a with same as the above TFCMK and VC solutions (0.001, 0.025, $0.005,0.075,0.01 \mathrm{mg} / \mathrm{mL}$ ) (Moo-Huchin et al., 2015).

The hydroxyl radical scavenging was determined following a protocol with TFCMK solutions $(0.06,0.13$, $0.25,0.50,0.75 \mathrm{mg} / \mathrm{mL})$ and $\mathrm{VC}$ solutions $(0.1,0.2,0.4$, $0.6,0.8 \mathrm{mg} / \mathrm{mL}$ ) (Hifney et al., 2016). 


\section{Antibacterial Activities}

The Minimum Inhibitory Concentration (MIC), defined as the lowest concentration of TFCMK to inhibit bacterial distinct growth, was detected by a broth microdilution method ( $\mathrm{Li}$ et al., 2017) with some modifications. B. subtilis, B. pumilus and E. coli strains were cultured in 96-well plates. The concentration decreased by 2 -fold to dilute the TFCMK into a gradient of $0.625-5.000 \mathrm{mg} / \mathrm{mL}$. Each well was added with the standard suspension of one of the strains $\left(10^{8} \mathrm{CFU} / \mathrm{mL}\right)$ and the final anhydrous ethanol in each well was used to dissolve the TFCMK, followed by incubation at $37^{\circ} \mathrm{C}$ for $24 \mathrm{~h}$. Chloramphenicol $(0.800-5.000 \mathrm{mg} / \mathrm{mL})$ was used as a positive control and the solution containing anhydrous ethanol without TFCMK was used as a negative control. All assays were repeated in triplicate.

\section{Hemolysis Rate}

The hemolysis rate of TFCMK assay was determined by a protocol (Chen, 2016).

The series of flavonoid solutions equivalent to the concentrations in the TFCMK solutions $(0.10,0.25,0.50$, $1.00,1.50,2.00 \mathrm{mg} / \mathrm{mL}$ ) were used as the experimental group, distilled water and normal saline were used as positive and negative controls respectively. The hemolysis rate of TFCMK was calculated as follows:

$$
\text { Hemolysis rate }(\%)=\left[\left(A_{s}-A_{c}\right) /\left(A_{p}-A_{c}\right)\right] \times 100 \%
$$

where, $A_{s}, A_{c}$ and $A_{p}$ are the absorbance of the test sample, negative control and positive control, respectively.

\section{Statistical Analysis}

The experimental data were statistically tested by Analysis of Variance (ANOVA) by IBM SPSS 24 and expressed as mean \pm standard error. The significant data at $p<0.05$ were calculated by Duncan's multiple range tests.

\section{Results and Discussion}

\section{Single-Factor Analysis}

\section{Effects of Ethanol Concentration on Extraction Rate of TFCMK}

The effects of ethanol concentration $(30 \%, 40 \%$, $50 \%, 60 \%, 70 \%)$ were investigated under the CMK dosage of $5 \mathrm{~g}$, temperature at $50^{\circ} \mathrm{C}$, liquid-to-solid ratio of $20 \mathrm{~mL} / \mathrm{g}$ and extraction time of $60 \mathrm{~min}$. The results are shown in Fig. 1a. The extraction rate of TFCMK were increased with the rise of ethanol concentration and maximized at $50 \%$. Because as the ethanol concentration increased, the polarity of the solvent decreased and the solubility of TFCMK was intensified, which were beneficial to the leaching of flavonoids. Whereas, at higher ethanol concentration, some higher polarity flavonoids may be precipitate due to poor solubility, which in turn affected the flavonoid extraction (Yang et al., 2017b).

\section{Effects of Liquid-to-Solid Ratio on Extraction Rate of TFCMK}

The effects of liquid-to-solid ratio $(10,20,30,40,50$ $\mathrm{mL} / \mathrm{g}$ ) were investigated under CMK dosage of $5 \mathrm{~g}$, temperature at $50^{\circ} \mathrm{C}$, extraction time of $60 \mathrm{~min}$ and ethanol concentration of $50 \%$. The extraction rate maximized at the liquid-to-solid ratio of $30 \mathrm{~mL} / \mathrm{g}$ (Fig.1b). because with the continuous increase of solvent ethanol, the concentration gradient between the solid and solvent was considered as mainly the driving force for mass, so that the flavonoid substances were dissolved more effectively (Xie et al., 2017). However, with above the liquid-to-solid ratio of $30 \mathrm{~mL} / \mathrm{g}$, the content of flavonoids was limited and more impurities were extracted. As a result, the extraction rate decreased.

\section{Effects of Extraction Time on Extraction Rate of TFCMK}

The effects of extraction time $(30,60,90,120,150$ min) were investigated under the CMK dosge of $5 \mathrm{~g}$, temperature at $50^{\circ} \mathrm{C}$, liquid-to-solid ratio of $30 \mathrm{~mL} / \mathrm{g}$ and ethanol concentration of $50 \%$. With the prolongation of extraction time, the extraction rate of TFCMK increased continuously and maximized at $90 \mathrm{~min}$ (Fig.1c). Because as the extraction time was prolonged, the plant cell walls were destroyed and the release quantity of flavonoids increased, which led to an increase in the extraction rate of TFCMK. However, when the extraction time was too long, promoting the degradation of polyphenols, thereby reducing the flavonoid extraction (Âahin et al., 2017).

\section{Effects of Extraction Temperature on Extraction Rate of TFCMK}

The effects of extraction temperature $(40,50,60,70$, $80^{\circ} \mathrm{C}$ ) were investigated under the CMK dosage of $5 \mathrm{~g}$, liquid-to-solid ratio at $30 \mathrm{~mL} / \mathrm{g}$, extraction time of 90 min and ethanol concentration of $50 \%$. With the rise of extraction temperature, the extraction rate of TFCMK increased and maximized at $60^{\circ} \mathrm{C}$ (Fig. 1d). At above $60^{\circ} \mathrm{C}$, the extraction rate began to decline. Due to the fact that low temperature dose not facilitate the diffusion of molecules, leading to the incompletion of extraction, while high temperature is prone to cause the degradation of bioactive constituents, both of which can induce the decrease of extraction yield (Ya et al., 2017).

\section{Optimization of Extraction Factors with RSM}

\section{Model Fitting Analysis}

Based on the experimental data of Table 2, a secondorder polynomial model (Equation 8) was used to predict the response value $Y$ (extraction rate/\%): 


$$
\begin{aligned}
& Y=6.23-0.23 \times X_{1}+0.19 \times X_{2}+0.096 \times X_{3}+0.12 \times X_{4}-0.45^{\prime} X_{1} \times X_{2} \\
& +0.11 \times X_{1} \times X_{3}-0.012 \times X_{1} \times X_{4}-0.031 \times X_{3} \times X_{4}+0.032 \times X_{2} \times X_{4} \\
& -0.038 \times X_{3} \times X_{4}-2.08 \times X_{1}^{2}-2.18 \times X_{2}^{2}-1.92 \times X_{3}^{2}-1.78 \times X_{4}^{2}
\end{aligned}
$$

where, $X_{1}, X_{2}, X_{3}$ and $X_{4}$ are the coded variables for the ethanol concentration (\%), liquid-to-solid ratio $(\mathrm{mL} / \mathrm{g})$, extraction time $(\mathrm{min})$ and extraction temperature $\left({ }^{\circ} \mathrm{C}\right)$, respectively.

\section{Fitting Model}

ANOVA confirms the response surface quadratic model has certain sufficiency and adaptability. The high $F$ value $(42.016)$ and low $P$ value $(<0.0001)$ (Table 3$)$ prove that the model has obvious significance and is very ideal. Comparison of $P$ values showed that the order of single factors affecting the model was ethanol concentration $\left(X_{1}\right)>$ liquid-to-solid ratio $\left(X_{2}\right)>$ extraction temperature $\left(X_{4}\right)>$ extraction time $\left(X_{3}\right)$. The coefficient of determination $R^{2}=0.9768$ suggests the model is reliable and can be used to interpret $97.68 \%$ of the data. According to the adjustment of the model, the adj- $R^{2}=$ 0.9535 indicates this model can predict most of the extracted variation $(>96 \%)$. The lack of fit $(p=0.1779)$ suggests the model is insignificant. Thus, the experimental results are obviously correlated with the theoretical values derived from the fitting of the corresponding polynomials. The model prediction is reliable and repeatable in the ranges of the parameters allowed. The ANOVA shows the model precision is
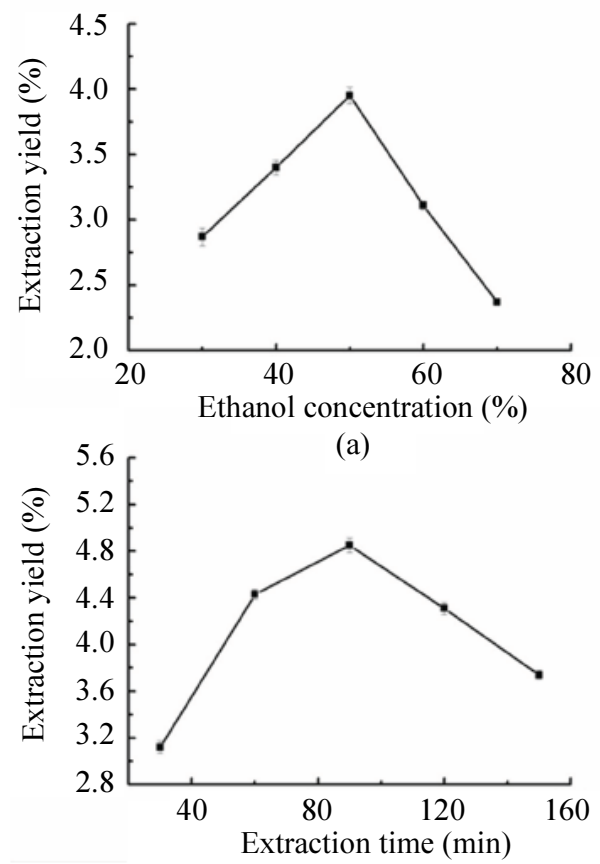

(c)
$19.340>4$ and the coefficient of variation is $11.36 \%$ $<30 \%$, indicating the model has high reproducibility, high accuracy and reliability (Qu et al., 2016). The model is suitable for analysis and prediction of the extraction results of TFCMK.

\section{Response Surface Analysis}

The specific response target and the corresponding independent variables were investigated via graphic analysis of response surface, which consists of 3D response surface plots that clearly reflect the impact of various factors on the response target. The $3 \mathrm{D}$ response surface plots comprehensively reflect the whole region of predictive behavior (AnnGiovannitti-Jensen and Myers, 1989) and can be obtained by finding the interaction of various factors in the reaction process. The effect of each factor on the extraction rate of TFCMK can be judged from the flexibility of the response surface plots (Fig. 2).

Firstly, the increase of ethanol concentration and the liquid-to-solid ratio, the extraction rate rises significantly and the result reversed if the ethanol concentration continues to increase (Fig. 2a). Furthermore, the interaction of these two factors significantly affects the extraction rate of TFCMK. Secondly, with the increase of ethanol concentration combined with the intermediate extraction time and extraction temperature, the change of extraction rate is relatively gentle (Fig. $2 b$ and c), indicating the interaction of ethanol concentration with extraction time or extraction temperature little affects the extraction rate.

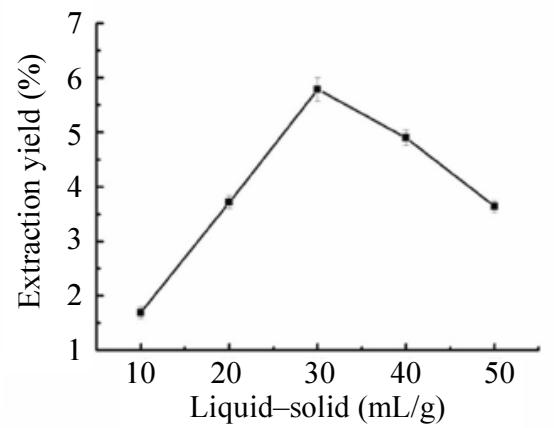

(b)

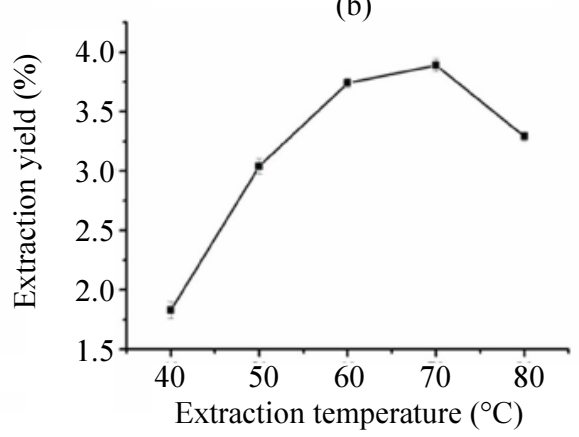

(d)

Fig. 1: Effects of (a) Ethanol concentration, (b) liquid-solid ratio, (c) extraction time and (d) extraction temperature on extraction rate of TFCMK. Data were shown as mean \pm SD $(n=3)$ 

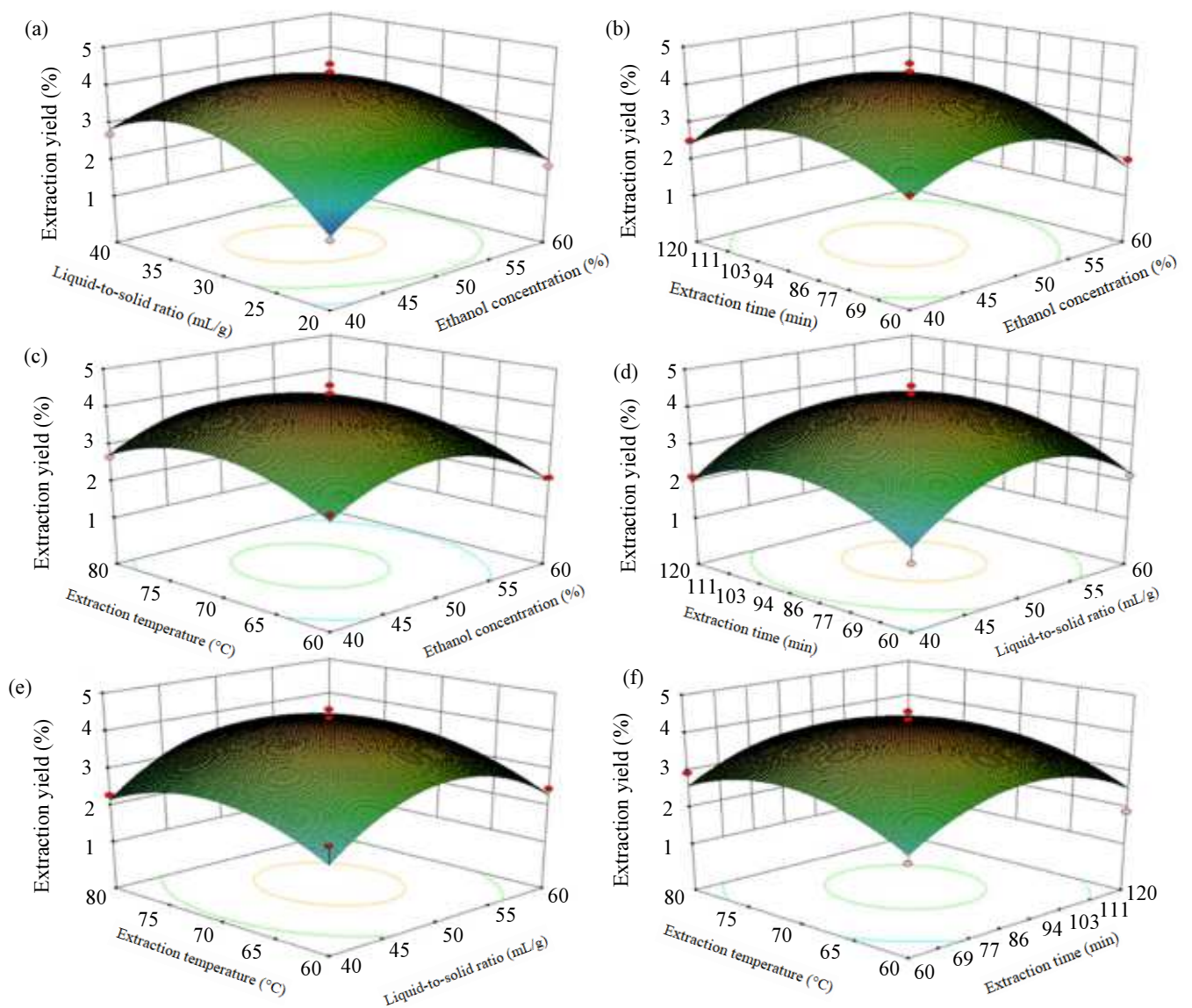

Fig. 2: Response surface of the effects of independent variables on the extraction yield of TFCMK. Extraction yield vs. (a) $X_{1}$ and $\mathrm{X}_{2}$, (b) $\mathrm{X}_{1}$ and $\mathrm{X}_{3}$, (c) $\mathrm{X}_{1}$ and $\mathrm{X}_{4}$, (d) $\mathrm{X}_{2}$ and $\mathrm{X}_{3}$, (e) $\mathrm{X}_{2}$ and $\mathrm{X}_{4}$ and (f) $\mathrm{X}_{3}$ and $\mathrm{X}_{4}$. Note: $\mathrm{X}_{1}$ : Ethanol concentration (\%), $\mathrm{X}_{2}$ : liquid- to-solid ratio $(\mathrm{mL} / \mathrm{g}), \mathrm{X}_{3}$ : Extraction time $(\mathrm{min}), \mathrm{X}_{4}$ : Extraction temperature $\left({ }^{\circ} \mathrm{C}\right)$

Table 3: ANOVA for the response surface quadratic model

\begin{tabular}{|c|c|c|c|c|c|c|}
\hline Source & Sum of squares & Degree of freedom & Mean square & F-value & P-value & Remarks \\
\hline Model & 68.6520 & 14.000 & 4.904 & 42.016 & $<0.0001$ & $* *$ \\
\hline $\mathrm{X}_{1}$ & 0.6320 & 1.000 & 0.632 & 5.416 & 0.0355 & * \\
\hline $\mathrm{X}_{2}$ & 0.4240 & 1.000 & 0.424 & 3.632 & 0.0774 & not significant \\
\hline$X_{3}$ & 0.1110 & 1.000 & 0.111 & 0.948 & 0.3467 & not significant \\
\hline $\mathrm{X}_{4}$ & 0.1840 & 1.000 & 0.184 & 1.579 & 0.2295 & not significant \\
\hline$X_{1} X_{2}$ & 0.7940 & 1.000 & 0.794 & 6.807 & 0.0206 & * \\
\hline$X_{1} X_{3}$ & 0.0470 & 1.000 & 0.047 & 0.402 & 0.5364 & not significant \\
\hline $\mathrm{X}_{1} \mathrm{X}_{4}$ & 0.0010 & 1.000 & 0.001 & 0.005 & 0.9448 & not significant \\
\hline $\mathrm{X}_{2} \mathrm{X}_{3}$ & 0.0040 & 1.000 & 0.004 & 0.033 & 0.8589 & not significant \\
\hline $\mathrm{X}_{2} \mathrm{X}_{4}$ & 0.0040 & 1.000 & 0.004 & 0.035 & 0.8537 & not significant \\
\hline $\mathrm{X}_{3} \mathrm{X}_{4}$ & 0.0060 & 1.000 & 0.006 & 0.049 & 0.8280 & not significant \\
\hline$X_{1}^{2}$ & 30.9110 & 1.000 & 30.911 & 240.820 & $<0.0001$ & ** \\
\hline$X_{2}^{2}$ & 24.0200 & 1.000 & 24.020 & 264.850 & $<0.0001$ & $* *$ \\
\hline$X_{3}^{2}$ & 20.5520 & 1.000 & 20.552 & 205.812 & $<0.0001$ & $* *$ \\
\hline$X_{4}^{2}$ & 68.6520 & 14.000 & 4.904 & 176.093 & $<0.0001$ & $* *$ \\
\hline Residual & 1.6300 & 14.000 & 0.120 & & & not significant \\
\hline Lack of Fit & 1.4200 & 10.000 & 0.140 & 2.670 & 0.1779 & not significant \\
\hline Pure error & 0.2100 & 4.000 & 0.530 & & & \\
\hline Cor Total & 70.2900 & 28.000 & & & & \\
\hline R-Squared & 0.9768 & & & & & \\
\hline Adj R-Squared & 0.9535 & & & & & \\
\hline Pred R-Squared & 0.8788 & & & & & \\
\hline C.V. \% & 11.6400 & & & & & \\
\hline Adeq Precision & 19.3400 & & & & & \\
\hline
\end{tabular}

**: Indicate highly significant $(p<0.01), *$ : Indicate significant $(p<0.05)$ 
Thirdly, the increase of liquid- to-solid ratio, the variation of extraction rate is not obvious and its interaction with the extraction time or extraction temperature does not obviously affect the response value (Fig. 2d and e). Finally, the increasing extraction time combined with the optimal extraction temperature, the response value is not obvious and has no significant effect on the model (Fig. 2f). To sum up, these results are consistent with the ANOVA.

\section{Verification of the Models}

The optimum extraction parameters (encoding extraction parameters: $0.060,0.049,0.022,0.035)$ were obtained on software through further analysis of the fitting linear equation. Ethanol concentration $49.40 \%$, liquid-to-material ratio $30.49 \mathrm{~mL} / \mathrm{g}$, extraction time $90.67 \mathrm{~min}$ and extraction temperature $70.35^{\circ} \mathrm{C}$ were obtained from Design-Expert software, where the theoretical extraction rate of TFCMK was $6.248 \%$. However, considering the operability in actual production, the optimum extraction parameters can be modified as follows: ethanol concentration is $50 \%$, liquid-to-material ratio is $31 \mathrm{~mL} / \mathrm{g}$, extraction time is 91 min and extraction temperature is $70^{\circ} \mathrm{C}$. The extraction rate of TFCMK is $6.240 \% \pm 0.04 \%$ from three repeated experiments under the optimum extraction conditions. The final experimental results are basically consistent with the predicted values on the software (relative error $=0.128 \%<2 \%$ ), indicating our model is suitable for the extraction of TFCMK and theoretically underlies the future development of CMK.

\section{Chemical Composition Analysis of TFCMK by LC- $M S / M S$}

The LC chromatogram at $254 \mathrm{~nm}$ and the total ion chromatogram (Fig. 3) were analyzed (Table 4). The compound $1\left(t_{R}=6.875 \mathrm{~min}\right)$ was identified as Catechin with the literature (Liu et al., 2009). The molecular formula is $\mathrm{C}_{26} \mathrm{H}_{28} \mathrm{O}_{14}$. The molecular ion peak [M-H] was at $\mathrm{m} / \mathrm{z} 289.0717$. Other fragment ions were $\mathrm{m} / \mathrm{z} 245$ $[(\mathrm{M}-\mathrm{H})-44]^{-}$and $\mathrm{m} / \mathrm{z} 203[(\mathrm{M}-\mathrm{H})-44-42]^{-}$that indicated the loss of the $\mathrm{C}_{2} \mathrm{H}_{2} \mathrm{O}^{-}$and $-\mathrm{COO}^{-}$groups, respectively (Henri et al., 2018).

The compound $2\left(t_{R}=7.905 \mathrm{~min}\right)$ was identified as Kaempferol-3, 7-di- $O$-glucoside with the literature (Francescato et al., 2013). The molecular formula is $\mathrm{C}_{27} \mathrm{H}_{30} \mathrm{O}_{17}$. The molecular ion $[\mathrm{M}-\mathrm{H}]^{-}$at $\mathrm{m} / \mathrm{z} 609.1461$ and the base ion fragment at $\mathrm{m} / \mathrm{z} 447[(\mathrm{M}-\mathrm{H})-162]^{-}$the exhibiting the loss of a glucose residue at the 7-O position, the other ion fragment at 285 $[(\mathrm{M}-\mathrm{H})-162-162]^{-}$, indicating a di-O-glycoside.

The compound $3\left(t_{R}=8.534 \mathrm{~min}\right)$ was identified as 6-C-arabinosyl-8-C-glucoside (isoschaftoside) with literature (Lai et al., 2016). The molecular formula is $\mathrm{C}_{26} \mathrm{H}_{28} \mathrm{O}_{14}$. The molecular ion $[\mathrm{M}-\mathrm{H}]^{-}$were $\mathrm{m} / \mathrm{z}$
563.1406 and the base ion fragments at $\mathrm{m} / \mathrm{z} 503$ [M$\mathrm{H}-60]^{-}$. Other fragment ions were $\mathrm{m} / \mathrm{z} 473$ [M-H-90] ${ }^{-}, 383[\mathrm{M}-\mathrm{H}-180]^{-}$(A [aglycone: Apigenin $\mathrm{M}-\mathrm{H}-270)]+113), 353[\mathrm{M}-\mathrm{H}-210]^{-}(\mathrm{A}+83)$ (Zhu et al., 2017).

The compound $4\left(t_{R}=9.049 \mathrm{~min}\right)$ was identified as orientin by comparison with literature (Tahir et al., 2012). The molecular formula is $\mathrm{C}_{21} \mathrm{H}_{20} \mathrm{O}_{11}$. The molecular ion $[\mathrm{M}-\mathrm{H}]^{-}$at $\mathrm{m} / \mathrm{z} 447.0959$ and the base fragment ions at $\mathrm{m} / \mathrm{z} 327[\mathrm{M}-\mathrm{H}-120]^{-}$. Other fragment ions were $\mathrm{m} / \mathrm{z} 357[\mathrm{M}-\mathrm{H}-90]^{-}, 297\left[\mathrm{M}-\mathrm{H}-\right.$ 150] $^{-}$, $285[\mathrm{M}-\mathrm{H}-162]^{-}$.

The compound $5\left(t_{R}=9.153 \mathrm{~min}\right)$ was identified as luteolin glucoside with literature (Sánchezrabaneda et al., 2003), showed a ion molecular $[\mathrm{M}-\mathrm{H}]^{-}$at $\mathrm{m} / \mathrm{z}$ 447.0928 and the base molecular fragment $\mathrm{m} / \mathrm{z} 285$ [M-H-glucosyl] ${ }^{-}$. The molecular formula is $\mathrm{C}_{27} \mathrm{H}_{30} \mathrm{O}_{16}$. This compound it was distinctly identified as luteolin glucoside, according to its mass spectrum fragment $\left([\mathrm{M}-\mathrm{H}]^{-}\right.$at $\mathrm{m} / \mathrm{z} 447$ and yielded to $\mathrm{m} / \mathrm{z}$ 285) and thus this compound was tentatively identified as luteolin glucoside.

The compound $6\left(t_{R}=11.143 \mathrm{~min}\right)$ was identified as rutin with literature (Chen et al., 2015). The molecular formula is $\mathrm{C}_{27} \mathrm{H}_{30} \mathrm{O}_{16}$. The molecular ion $[\mathrm{M}-\mathrm{H}]^{-}$at $\mathrm{m} / \mathrm{z}$ 609.1452 and the base ion fragment at $\mathrm{m} / \mathrm{z} 301[\mathrm{M}-\mathrm{H}-90]^{-}$ (Ćirić et al., 2012), exhibited the loss of their glycosyl groups and corresponding to quercetin aglycone.

The compound $7\left(t_{R}=13.704 \mathrm{~min}\right)$ was identified as luteolin-7-O- $\beta$-D-glucuronide with literature (Ćirić et al., 2012). The molecular formula is $\mathrm{C}_{21} \mathrm{H}_{18} \mathrm{O}_{12}$. The molecular ion $[\mathrm{M}-\mathrm{H}]^{-}$at $\mathrm{m} / \mathrm{z} 461.0733$ (Li et al., 2017) and the base ion fragment at $\mathrm{m} / \mathrm{z} 285$, exhibited the flavone $O$-glycosides.

The compound $8\left(t_{R}=16.329 \mathrm{~min}\right)$ was identified as isochlorogenic acid B with literature (Yin et al., 2013). The molecular formula is $\mathrm{C}_{25} \mathrm{H}_{2} 4 \mathrm{O}_{12}$. While ion peak $[\mathrm{M}-\mathrm{H}-163]^{-}$at $\mathrm{m} / \mathrm{z} 515.1207$, the first cracking reaction occurs when the caffeoyl fragment at $\mathrm{m} / \mathrm{z} 163$ is lost and the base ion fragment at $\mathrm{m} / \mathrm{z} 353$ [M-H-163-192] (Li et al., 2017), On this basis, some fragments of quinic acid group were separated again, the fragments at m/z 192 were lost and the fragments of caffeoyl group remained, resulting in ion fragments at $\mathrm{m} / \mathrm{z} 161$. It indicated that two caffeoyl groups existed in the chemical structure.

The compound $9\left(t_{R}=22.369 \mathrm{~min}\right)$ was identified as luteolin with literature (Toplan et al., 2017). The molecular formula is $\mathrm{C}_{15} \mathrm{H}_{10} \mathrm{O}_{6}$. The molecular ion peak $[\mathrm{M}-\mathrm{H}-28]^{-}$at $\mathrm{m} / \mathrm{z} 285.0392$ and 257 were obtained by the loss of $-\mathrm{CO}$ from the fragment ion peak at $\mathrm{m} / \mathrm{z} 257$ and 229. The fragment ions $\mathrm{m} / \mathrm{z} 151$ and 133 were obtained by RDA cleavage of fragment ions $\mathrm{m} / \mathrm{z} 285$. It is presumed that the compound was luteolin and the base ion fragments at $\mathrm{m} / \mathrm{z} 199$. Other ions fragment were $\mathrm{m} / \mathrm{z}$ 175 and 151. In addition base peak at $\mathrm{m} / \mathrm{z} 133$ was obtained by the RDA cleavage of the structure. 
The compounds of $10-12$ in Table 4 were found to contain $\mathrm{m} / \mathrm{z} 285[\mathrm{M}-\mathrm{H}]^{-}$by $\mathrm{MS} / \mathrm{MS}$ fragments, it is speculated that they belongs to such luteolin flavonoids. At present, there are no reports of using LC-MS/MS to analyze the flavonoids of TFCMK and with many isomers. The two peaks at $t_{R}=23.560 \mathrm{~min}$ were not separated so that they could not be resolved. Therefore, the analytical constituents was need to be improved.

\section{Antioxidant Activity}

Antioxidants can prevent hydroxyl radicals from destroying biological macromolecules. The ability to scavenge hydroxyl radicals is directly related to the antioxidant capacity (Cacciuttolo et al., 1993). The antioxidant experiment results of the four systems includes the reducing power scavenging activity, DPPH. scavenging activity, $\mathrm{ABTS}^{+}$and Hydroxyl radicals of both TFCMK and VC were enhanced with the increasing concentration (Fig. 4a-d). The $\mathrm{EC}_{50}$ or $\mathrm{IC}_{50}$ values of TFCMK were $0.125 \pm 0.025,0.28 \pm 0.031,0.012 \pm 0.005$ and $0.028 \pm 0.008 \mathrm{mg} / \mathrm{mL}$ and the $\mathrm{EC}_{50}$ or $\mathrm{IC}_{50}$ values of $\begin{array}{lll}\text { VC } \quad 0.156 \pm 0.012, & 0.059 \pm 0.019, & 0.068 \pm 0.024\end{array}$ and $0.032 \pm 0.007 \mathrm{mg} / \mathrm{mL}$, respectively. Results suggest TFCMK have significant antioxidant activity, which showed stronger in the system of reducing power and scavenging hydroxyl radicals. Firstly, the possible reason mainly is the phenolic hydroxyl structures of flavonoids play an antioxidant role through the reduction of phenolic hydroxyl. All the 9 compounds have phenolic hydroxyl groups and benzene ring structure. The reaction of phenolic hydroxyl with free radicals produces a stable structure and terminates the free radical chain reaction. Phenolic hydroxyl radicals are mainly produced by ionizing hydrogen atoms, neutralizing oxygen free radicals and combining with ionized flavonoids to form dimers, which prevent reverse binding and thus scavenge radicals (Boulanouar et al., 2013; Karmakar et al., 2013). Secondly, the effect of double bonds in the structural nucleus of flavonoids is also crucial to the oxidation resistance. Theoretically, double bonds act as electron delocalization and lengthen the conjugation system, which is conducive to the formation of more stable free radicals after the electron loss in flavonoid nuclei and then interrupts the chain reaction (Acheampong et al., 2016).

\section{Antibacterial Activity}

TFCMK showed significant antibacterial activity against B. pumilus, B. subtilis and, E. coli according to the MIC with in $0.625-5.000 \mathrm{mg} / \mathrm{mL}$ (Table 5). Among them, the MIC of B pumilus was $0.625 \mathrm{mg} / \mathrm{mL}$, which exhibited a higher inhibition effect, as evidenced by the MIC of Chloramphenicol was less than $0.8 \mathrm{mg} / \mathrm{mL}$. The cooperation effects of the above 9 compounds can not be excluded. The a ntibacterial mechanism of TFCMK may be through its own hydrophobic (Zhou et al., 2018) in teraction with the lipid bilayer of the bacterial cell membrane and it can affect the stability of the cell membrane to achieve bactericidal effect (Taylor, 2013; Veloza and Mantillamuriel, 2014). The antimicrobial effect of flavonoids is mainly due to the destruction of bacterial cell membrane by their hydrophobic benzene ring, thus achieving the purpose of sterilization. The antibacterial 1 mechanisms of TFCMK need further research. With the widespread application and abuse of antibiotics, more and more drug-resistant strains are found in clinic. The development of natural plant antibacterial agent with the lower MIC has become a new method to solve the problem of bacterial resistance.

\section{Hemolysis Analysis}

To test whether TFCMK possessed a blood compatibility, the hemolysis test which was used to detect degree or proportion of damage to red blood cells, was carried out (Zhang et al., 2017). According to the International Organization for Standardization (ISO), the hemolysis rate $\leq 5 \%$ suggests the sample meets the hemolysis requirement of medical treatment and the hemolysis rate $>5 \%$ indicates the occurrence of hemolysis. The results are shown in Fig. 5. In the concentration range of $0.1-2.0 \mathrm{mg} / \mathrm{mL}$, the hemolysis rate declines, but is less than $5 \%$, indicating TFCMK meets the hemolysis requirement of medical treatment in this concentration range (Sobrinho et al., 2016). Thus, it is affirmed that TFCMK can be applied for pharmaceutical and chemical industries.

Table 4: Chemical constituents of TFCMK

\begin{tabular}{|c|c|c|c|c|c|c|}
\hline No. & $t R(\min )$ & {$[\mathrm{M}-\mathrm{H}]^{-}(\mathrm{m} / \mathrm{z})$} & Error(ppm) & Molecular formula & Ion fragment & Compound \\
\hline 1 & 6.8750 & 289.0717 & -1.26 & $\mathrm{C}_{15} \mathrm{H}_{14} \mathrm{O}_{6}$ & $245,203,188,187,161,137,125,109,57,45$ & Catechin \\
\hline 2 & 7.9050 & 609.1461 & -0.70 & $\mathrm{C}_{27} \mathrm{H}_{30} \mathrm{O}_{16}$ & $609,571,539,489,447,327,285,227,151$ & Kaempferol-3,7-di-O-glucoside \\
\hline 3 & 8.5340 & 563.1406 & 1.550 & $\mathrm{C}_{26} \mathrm{H}_{28} \mathrm{O}_{14}$ & $545,503,473,443,413,383,353,325,297,59$ & $\begin{array}{l}\text { 6-C-Arabinosyl-8-C-glucoside } \\
\text { (isoschaftoside) }\end{array}$ \\
\hline 4 & 9.0490 & 447.0902 & 2.640 & $\mathrm{C}_{21} \mathrm{H}_{20} \mathrm{O}_{11}$ & $357,339,327,297,285,269,175,151,41$ & Orientin \\
\hline 5 & 9.1530 & 447.0928 & 2.640 & $\mathrm{C}_{21} \mathrm{H}_{20} \mathrm{O}_{11}$ & $357,339,327,297,285,269,175,151,41$ & Luteolin glucoside \\
\hline 6 & 11.143 & 609.1452 & 3.840 & $\mathrm{C}_{27} \mathrm{H}_{30} \mathrm{O}_{16}$ & $573,503,461,387,301,285,257,181,179,151$ & Rutin \\
\hline 7 & 13.704 & 461.0733 & -1.77 & $\mathrm{C}_{21} \mathrm{H}_{18} \mathrm{O}_{12}$ & $374,327,357,301,285,269,241,203,179,130,85,56$ & $\begin{array}{l}\text { Luteolin-7-O-ß-d- } \\
\text { glucuronide }\end{array}$ \\
\hline 8 & 16.329 & 515.1207 & -4.22 & $\mathrm{C}_{25} \mathrm{H}_{24} \mathrm{O}_{12}$ & $405,353,265,173,135,44$ & Isochlorogenic acid B \\
\hline 9 & 22.369 & 285.0392 & 4.740 & $\mathrm{C}_{15} \mathrm{H}_{10} \mathrm{O}_{6}$ & $243,199,175,151,133,121,107,65,41$ & Luteolin \\
\hline 10 & 11.400 & 593.1491 & 1.700 & $\mathrm{C}_{27} \mathrm{H}_{30} \mathrm{O}_{15}$ & $573,447,387,285,269,165$ & Unknow \\
\hline 11 & 12.592 & 447.0895 & 4.500 & $\mathrm{C}_{21} \mathrm{H}_{20} \mathrm{O}_{11}$ & $125,151,178,271,285,300,327$ & Unknow \\
\hline 12 & 16.877 & 505.1972 & 2.410 & $\mathrm{C}_{23} \mathrm{H}_{22} \mathrm{O}_{13}$ & $434,315,285,227,134,44$ & Unknow \\
\hline
\end{tabular}


Table 5: Minimal Inhibitory Concentrations (MIC) of TFCMK

\begin{tabular}{lcccr}
\hline Sample & Unit & B. pumilus & B. subtilis & E. coli \\
\hline TFCMK & $\mathrm{mg} / \mathrm{mL}$ & 0.625 & 1.250 & 5.000 \\
Chloramphenicol & $\mathrm{mg} / \mathrm{mL}$ & $<0.800$ & $<0.800$ & $<0.800$ \\
\hline
\end{tabular}

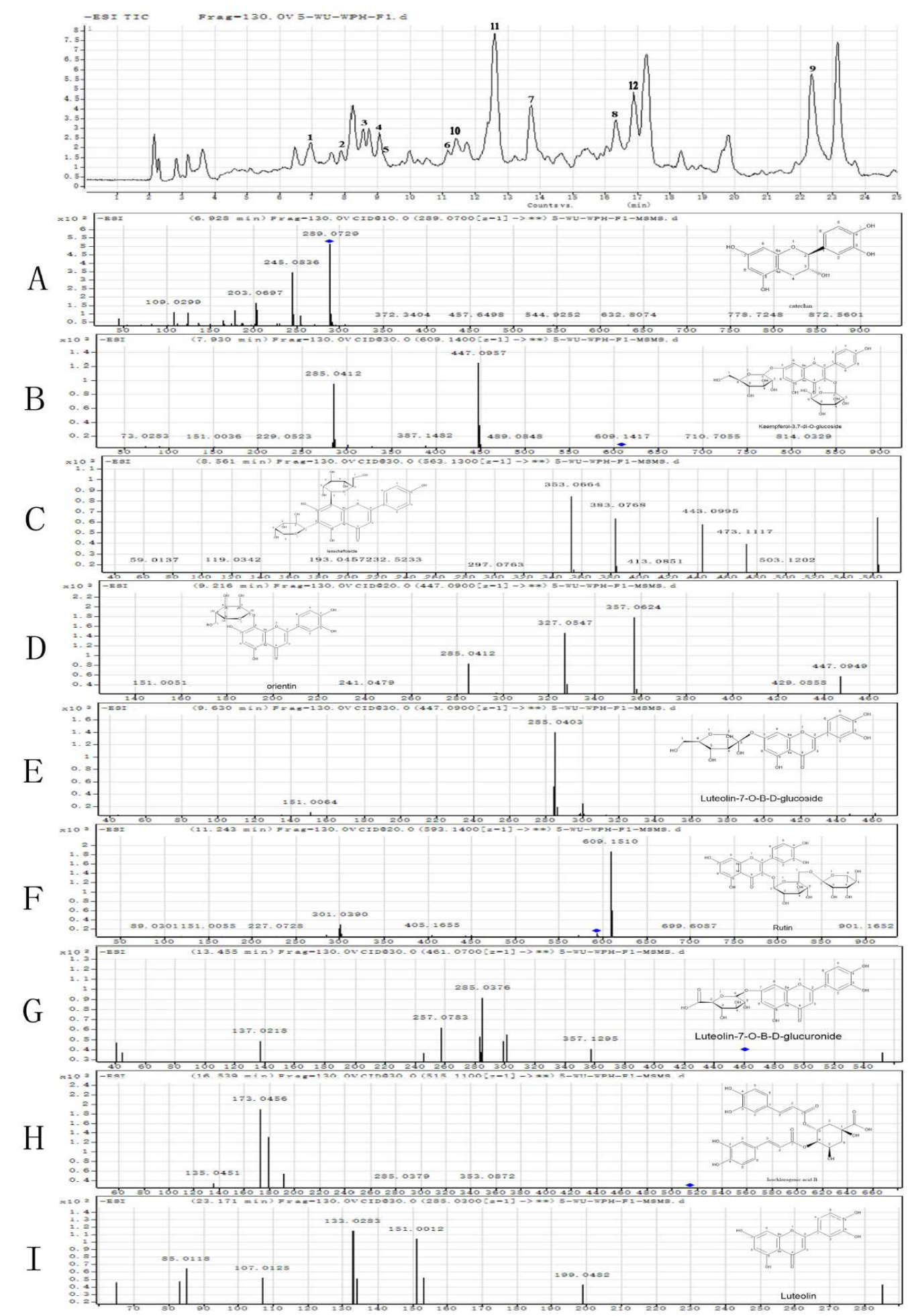

Fig. 3: ESI total ion flow diagram and chemical structures of A-I 


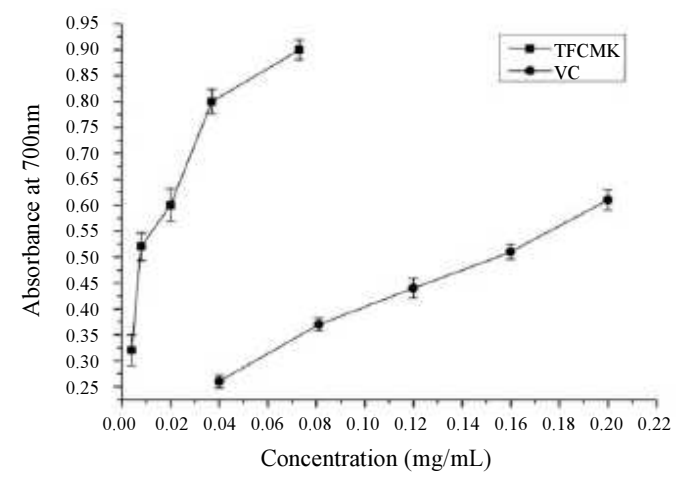

(a)

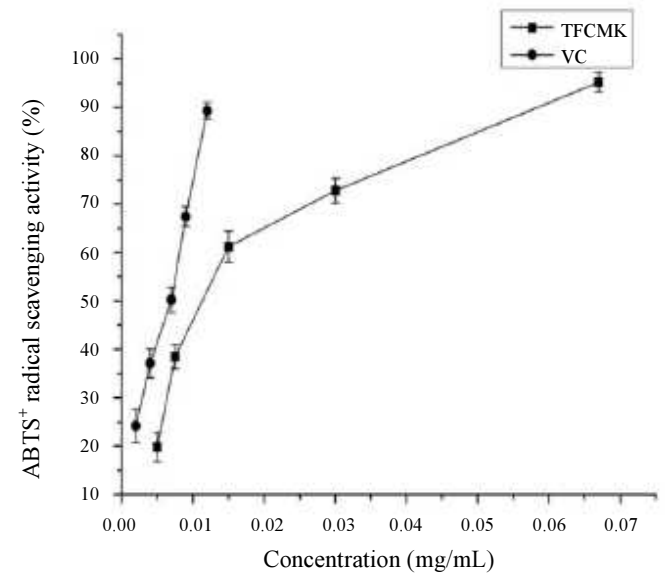

(c)

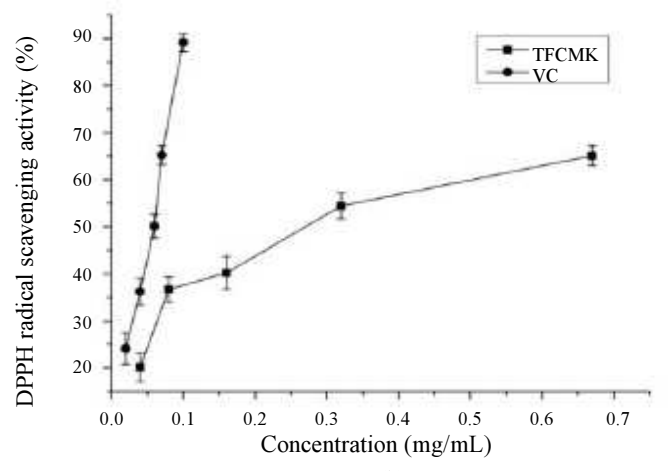

(b)

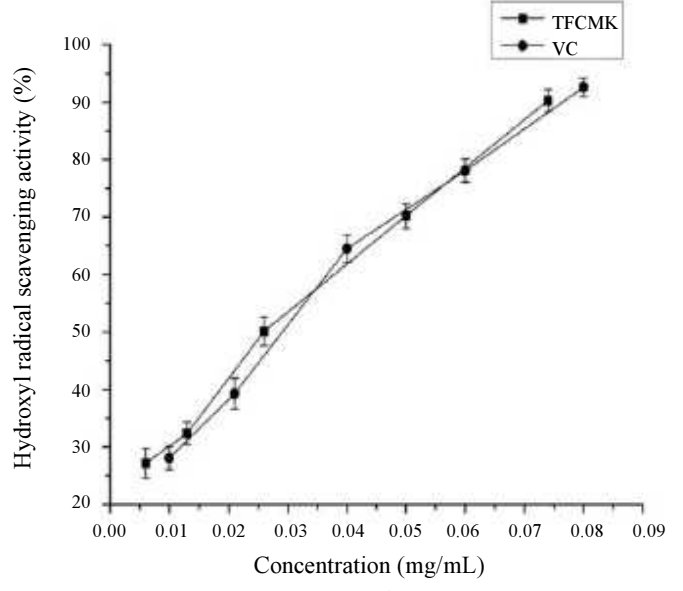

(d)

Fig. 4: Antioxidant activities of TFCMK. (a) Reducing power assay; (b) DPPH, (c) ABTS+ and (d) Hydroxyl radical scavenging assays

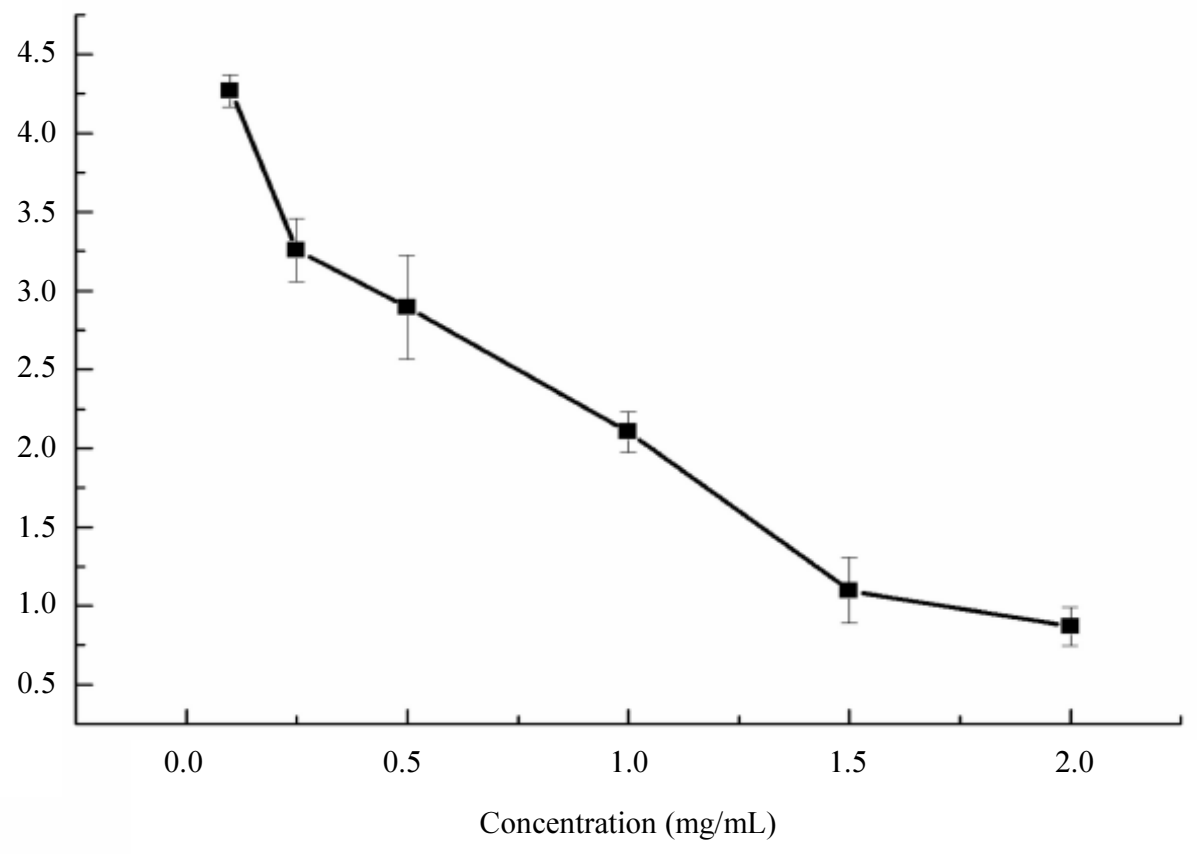

Fig. 5: Hemolysis rate of flavonoids from TFCMK 


\section{Conclusion}

The maximum extraction yield of TFCMK was observed under the optimal condition and the actual yield reached at $6.24 \% \pm 0.04 \%$. Meanwhile, 9 compounds of TFCMK firstly identified by LC-MS/MS. In addition, TFCMK possessed a higher antioxidant activity and antibacterial activity, quantified by the $\mathrm{IC}_{50}$ and MICs; in vitro assay, hemolysis rate was less than $5 \%$. The above data indicates that TFCMK might be applied as an antioxidant and antibacterial agent in the pharmaceutical and chemical industries. Herein, this study underlies further research on CMK in the future.

\section{Acknowledgement}

This investigation was supported by the programs of Jilin Province Development and Reform Commission (Grant No. 2019C045-4), the Science and Technology Bureau of Jilin City (Grant No. 201851869), the Science and Technology Department of Jilin province (Grant No. 20190304102YY).

\section{Author's Contributions}

Hongbiao Wang and Penghui Wang: The antioxidant, antimicrobial and hemolytic experiments were studied and analyzed in detail.

Xiudong Yang: The revision and proofreading of the manscript was completed.

Xianhe Cheng and Chun Liu: The chemical composition of TFCMK by LC-MS/MS was analyzed.

Mengru Dong, Ziqiang Yan and Yuejiao Guo: Response Surface Methodology (RSM) was mainly explored.

Hongli Zhou: The design route and experimental guidance of this manuscript were guided.

\section{Ethics}

This article is original and contains unpublished material. The corresponding author confirms that all of the other authors have read and approved the manuscript and no ethical issues involved.

\section{References}

Åahin, S., S. Ruya and Z.T.A.S. Birteks, 2017. Solventfree microwave-assisted extraction of polyphenols from olive tree leaves: Antioxidant and antimicrobial properties. Molecules, 22: 1056-1056. DOI: $10.3390 /$ molecules22071056

Acheampong, F., C. Larbie and R. Appiag-Opong, 2016. In vitro antioxidant and anticancer properties of hydroethanolic extracts, fractions and novel flavones of Ageratum conyzoides leaves. Planta Med., 81: 30-36. DOI: 10.1055/s-0036-1596364
AnnGiovannitti-Jensen, M.R., 1989. Graphical assessment of the prediction capability of response surface designs. Technometrics, 31: 159-171. DOI: 10.2307/1268814

Boulanouar, B., G. Abdelaziz, S. Aazza and C. Gago, 2013. Antioxidant activities of eight Algerian plant extracts and two essential oils. Indus. Crops Products, 46: 85-96. DOI: 10.1016/j.indcrop.2013.01.020

Cacciuttolo, M.A., L. Trinh and J.A. Lumpkin, 1993. Hyperoxia induces DNA damage in mammalian cells. Free Radical Bio. Med., 14: 267-276. DOI: 10.1016/0891-5849(93)90023-N

Chen, L.I., L.U. Xiaotengjia and T. Huarong, 2015. Analysis of phenolic compounds in mulberry by high performance liquid chromatographyltime of flight mass spectrometry. Food Sci., 36: 1011104-1011104. DOI: 10.7506/SPKX1002-6630-201502019

Chen, Y., L. Zhao and B. Liu, 2012. Application of response surface methodology to optimize microwave-assisted extraction of polysaccharide from Tremella. Phys. Procedia, 24: 429-433. DOI: 10.1016/J.PHPRO.2012.02.063

Chen, Z., 2016. Chemical compositions and antibacterial activities of essential oils extracted from Alpinia guilinensis against selected foodborne pathogens. Indus. Crops Products, 83: 607-613. DOI: 10.1016/J.INDCROP.2015.12.063

Ćirić, A., H. Prosen and M. Jelikić-Stankov, 2012. Evaluation of matrix effect in determination of some bioflavonoids in food samples by LC-MS/MS method. Talanta, 99: 780-790. DOI: $10.1016 /$ j.talanta.2012.07.025

Cui, H., H.W. Pan and P.H. Wang, 2018. Essential oils from Carex meyeriana Kunth: Optimization of hydrodistillation extraction by response surface methodology and evaluation of its antioxidantand antimicrobial activities. Indus. Crops Products, 124: 669-676. DOI: 10.1 016/ j.indcrop.2018.08.041

Dong, R., J. Su and N. Hua, 2017. Chemical fingerprint and quantitative analysis of flavonoids for quality control of Sea buckthorn leaves by HPLC and UHPLC-ESIQTOF-MS. J. Funct. Foods, 37: 513-522. DOI: 10.1016/J.JFF.2017.08.019

Francescato, L.N., S.L Debenedetti and T.G. Schwanz, 2013. Identification of phenolic compounds in Equisetum giganteum by LC-ESI-MS/MS and a new approach to total flavonoid quantification. Talanta, 105: 192-203.

DOI: 10.1016/J.TALANTA.2012.11.072

Henri, M.N., E. Pinault, V. Gloaguen, G. Costa and L. Mambu et al., 2018. Profiling and seasonal variation of chemical constituents from pseudotsugamenziesii wood. J. Indus. Crops Products, 117: 34-49. DOI: 10.3321/j.issn:0251-0790.2009.08.017 
Hifney, A.F., M.A. Fawzy and K.M. Abdel-Gawad, 2016. Industrial optimization of fucoidan extraction from Sargassum, SP. and its potential antioxidant and emulsifying activities. Food Hydrocoll., 54: 77-88. DOI: 10.1016/j.foodhyd.2015.09.022

$\mathrm{Hu}$, Z., P. Wang and H. Zhou, 2018. Extraction, characterization and in vitro antioxidant activity of polysaccharides from Carex meyeriana Kunth using different methods. Int. J. Biol. Macromolecules, 120: 2155-2164. DOI: 10.1016/j.ijbiomac.2018.09.125

Karmakar, A., T. Mallick, M.N. Alam, A. Kumar and P. Sharma et al., 2017. Exploration of antioxidant activity of newly synthesized azo flavones and its correlation with electrochemical parameters along with the study of their redox behaviour. J. Anal. Chem., 72: 10341044. DOI: 10.1134/S1061934817100094

Li, H., D. Zhang and L.H. Tan, 2017. Comparison of the antioxidant properties of various solvent extracts from Dipsacus as peroides and identification of phenolic compounds by LC-ESI-QTOF-MS-MS. South African J. Botany, 109: 1-8. DOI: $10.1016 /$ j.sajb.2016.12.018

Li, J.E., S.T. Fan and Z.H. Qiu, 2015. Total flavonoids content, antioxidant and antimicrobial activities of extracts from mosla Chinensis maxim. cv. jiangxiangru. LWT-Food Sci. Technol., 64: 1022-1027. DOI: $10.1016 /$ j.lwt.2015.07.033

Lai, L.C., L. Yu-Ying, C. Feng-Lian and L. Xiao-Ping, 2016. Analysis of main active components in Desmodii Stymciflii Herba by HPLC-QTOF-MS and HPLC-DAD. Chinese Trad. Herb. Drugs. DOI: $10.7501 /$ j.issn.0253-2670.2016.20.006

Liu, Z.C., L.K. Zhang and Y.U. Chang, 2012. Optimization of ultrasound-assisted extraction of flavonoids from germinated brown rice using response surface methodology. Food Sci., 33: 80-84. DOI: 10.7506/spkx1002-6630-201208017

Luo, M. and J.Y. Zhang, 2008. Chinese Carex meyeriana Kunth, Jilin Peoples Press, Changchun, 19-23. (In Chinese).

Liu, G.Q., D. Jing and W. Hong, 2009. ESI fragmentation studies of four tea catechins. Chem. J. Chinese Uni., 30: 1566-1570. DOI: $10.3321 / \mathrm{j}$.issn:0251-0790.2009.08.017

Mendes, L., F.V. De and P. Baptista, 2011. Comparative antihemolytic and radical scavenging activities

Moo-Huchin, V.M., M.I. Moo-Huchin and R.J.N. Estrada-Leã, 2015. Antioxidant compounds, antioxidant activity and phenolic content in peel from three tropical fruits from Yucatan, Mexico. Food Chem., 166: 17-22.

DOI: 10.1016/j.foodchem.2014.05.127
Mou, Q., J. He and R. Yin, 2017. Response surface optimized infrared-assisted extraction and UHPLC determination of flavonoid types from Flos Sophorae. Molecules, 22: 1000-1000. DOI: 10.3390/molecules22061000

Chen, Y., L. Zhao and B. Liu, 2012. Application of strawberry tree (Arbutus unedo L.) leaf and fruit. Food Chem. Toxicol., 49: 2285-2291.

DOI: $10.1016 /$ j.fct.2011.06.028

Qu, Y., C. Li and C. Zhang, 2016. Optimization of infrared-assisted extraction of Bletilla striata polysaccharides based on response surface methodology and their antioxidant activities. Carbohydrate Polymers, 148: 345-353. DOI: 10.1016/j.carbpol.2016.04.081

Reznicek, A.A., 1990. Evolution in sedges (carex, cyperaceae). Can. J. Bot., 68: 1409-1432. DOI: $10.2307 / 2996698$

Sánchezrabaneda, F., O. Jáuregui and R.M. Lamuelaraventós, 2003. Identification of phenolic compounds in artichoke waste by high-performance liquid chromatography-tandem mass spectrometry. J. Chromatography, 1008: 57-72. DOI: 10.10 16/S0021-9673(03)00964-6

Sobrinho, A.C.N., E.B.R. De Souza and F.G. Marcos, 2016. Chemical composition, antioxidant, antifungal and hemolytic activities of essential oil from Baccharis trinervis (Lam.) Pers. (Asteraceae). Indus. Crops Products, 84: 108-115. DOI: $10.1016 /$ j.indcrop.2016.01.051

Tahir, N.I., K. Shaari and F. Abas, 2012. Characterization of apigenin and luteolin derivatives from oil palm (Elaeis guineensis Jacq.) Leaf Using LC-ESI-MS/MS. J. Agri. Food Chem., 60: 11201-11210. DOI: $10.1021 / \mathrm{jf3} 03267 \mathrm{e}$

Taylor, P.W., 2013. Alternative natural sources for a new generation of antibacterial agents. Int. J. Antimicrobial. Agents, 42: 195-201. DOI: 10.1016/j.ijantimicag.2013.05.004

Toplan, G.G., M. Kurkcuoglu and F. Goger, 2017. Composition and biological activities of Salvia veneris Hedge growing in Cyprus. Indus. Crops Products. 97: 41-48. DOI: $10.1016 /$ j.indcrop.2016.11.055

Veloza, S.A.L.A. and L.E. Mantillamuriel, 2014. Anti-toxoplasma activity of natural products: A review. Recent Patents Anti-Infective Drug Disco., 9: 186-94. PMID: 25858302

Wang, W., X. Wang and H. Ye, 2016. Optimization of extraction, characterization and antioxidant activity of polysaccharides from brassica Rapa, 1. Int. J. Biol. Macromolecules, 82: 979-988. DOI: $10.1016 / j$.ijbiomac.2015.10.051

Wang, Y., Y. Gao and H. Ding, 2017. Subcritical ethanol extraction of flavonoids from Moringa oleifera leaf and evaluation of antioxidant activity. Food Chem., 218: 152-158. DOI: 10.1016/J.FOODCHEM.2016.09.058 
Xie, G., R. Li and Y. Han, 2017. Optimization of the extraction conditions for buddleja officinalis maxim. using response surface methodology and exploration of the optimum harvest time. Molecules, 22: 18771877-1877. DOI: 10.3390/MOLECULES22111877

Ya, L., L. Sha and L. Sheng-Jun, 2017. Microwaveassisted extraction of natural antioxidants from the exotic gordonia axillaris fruit: Optimization and identification of phenolic compounds. Molecules, 22: 1481-1481. DOI: 10.3390/molecules22091481

Yang, S., S. Fan and Z Wang, 2016. Ethanol reflux method extraction and antioxidant activities of total flavonoids from lycopodii herba. Northern Horticulture. DOI: 10.11937/bfyy.201606029

Yang, X., H. Liu and F. Han, 2017a. Fabrication of cellulose nanocrystal from Carex meyeriana Kunth and its application in the adsorption of methylene blue. Carbohydrate Polymers, 175: 464-464. DOI: 10.1016/j.carbpol.2017.08.007

Yang, L., P. Yin and H. Fan, 2017b. Response surface methodology optimization of ultrasonic-assisted extraction of acer truncatum leaves for maximal phenolic yield and antioxidant activity. Molecules., 22: 232-232. DOI: 10.3390/MOLECULES22020232

Yin, R., F. Han and Z. Tang, 2013. UFLC-MS/MS method for simultaneous determination of luteolin7-O-gentiobioside, luteolin-7-O- $\beta$-d-glucoside and luteolin-7-O- $\beta$-d-glucuronide in beagle dog plasma and its application to a pharmacokinetic study after administration of traditional Chinese medicinal preparation: Kudiezi injection. J. Pharmaceutical Biomed. Anal., 72: 127-133.

DOI: $10.1016 /$ j.jpba.2012.09.028
Yun, W., B. Teng and S. Qiu, 2016. Self-activated Carex meyeriana Kunth-based porous carbon prepared by direct carbonization and its electrochemical properties. Chemical J. Chinese Uni. DOI: $10.7503 / C J C U 20160075$

Zhang, E., J. Li and Y. Zhou, 2017. Biodegradable and injectable thermoreversible xyloglucan based hydrogel for prevention of postoperative adhesion. Acta Biomate., 17: 706-730. DOI: $10.1016 /$ j.actbio.2017.04.003

Zhou, W., Y. Zhou and J.J. Zhang, 2018. Modification of fish scale gelatin edible films using flavonoids with different hydroxyl structures. Shipin Kexue/Food Sci., 39: 78-85. DOI: $10.7506 /$ spkx1002-6630-201820012

Zhu, J.W., W. Chunhua, M. Jing, Z. Guoyue and J.A. Zeng, 2017. Analytical studies on flavonoids of coluria longifolia maxim by UHPLC-Q-TOF-MS. Trad. Chinese Med. J., 16: 59-63. DOI: 10.13207/j.cnki.jnwafu.2017.06.025 